\title{
The Map of the Bosnia or Đakovo and Syrmia Diocese
}

\author{
Brankica MALIĆ, Stanislav FRANGEŠ
}

\begin{abstract}
The article describes the early thematic map of the Bosnia or Đakovo and Syrmia Diocese from the year 1826 (later in text Diocese of Đakovo and Syrmia). The map is a valuable historical document that elaborates more than just ecclesiastical contents. The diocese was partly situated in the area of today's Republic of Croatia and Republic of Serbia. It is situated in the area surrounded by the rivers Sava, Drava and Danube which constitute the south, north and east borders of the diocese, whereas the west border roughly spreads from Slavonski Brod to Donji Miholjac. Possible map originals, as well as their authors, Demetrü Görög and Joannis Lipszky, are mentioned. The text contains the historical overview of development of the diocese. Ecclesiastical, secular and natural contents of the map are elaborated in detail. The legend is also translated and tabular views are given about different religions of the area.
\end{abstract}

Keywords: cartographic symbols; diocese; language; religion; thematic map

\section{INTRODUCTION}

The article elaborates the map of the Bosnia or Đakovo and Syrmia Diocese, with the original title: "Mappa Dioecesium Bosnensis seu Diakovariensis et Syrmiensis". The authors of the map are Demetrü Görög and Joannis Lipszky, and the existing exemplars of the map are from 1826.

The map exemplars are stored at the Museum of Slavonia in Osijek in Croatia as well as at the Diocesan Archives in Đakovo. There are four equivalent maps at the Diocesan Archives, three exemplars are framed and the fourth is rolled up and stored in the archives.

This is a thematic map which specifically emphasizes ecclesiastical contents. The map contains abundant information about topographical, historical and toponomastical elements. All textual data included in the map is in Latin and this article provides its translation.

\section{THE CONTENT OF THE MAP}

The map was made by the aforementioned authors Demetrü Görög and JoannisLipszky on the request of Bishop Emerici Caroli Raffay. The original title was "Mappa Dioecesium Bosnensisseu Diakovariensis et Syrmiensis" and it was printed in Budapest in 1826 in Francisca Karacs's copper workshop. Many other maps had been reproduced in this workshop e.g. Szeman's map of the Diocese of Zagreb from 1822, the Postal map of the Kingdom of Hungary from 1802, Lipszky's map of Hungary from 1806, Beischlag's map of the Varaždin's county from 1802 and the geographical atlases (Österreichisches Biographisches Lexikon, 1815-1950) [1, 2].

The map is printed on one sheet. The dimensions of the useful map space are $80,8 \times 50,7 \mathrm{~cm}$, whereas the dimensions of the map including the ornamental frame are $95,7 \times 56,4 \mathrm{~cm} \mathrm{[3]} \mathrm{(in} \mathrm{Fig.} \mathrm{1).}$

The map was made in the form of the so called insel map, i.e. the map does not include any outer content of the Diocese of Đakovo and Syrmia, except that of the area of Baranja. The remaining area, to the ornamental map's frame, contains different textual data and classicistic drawings. The outer part of the map's frame is shaped by a thicker contour frame and the inside of the frame includes stylized leaves on a hatched background.

The title of the map is placed in the upper left corner inside the rectangular vignette and except the title, the name of bishop Raffay, who ordered the map, is written. The coat of arms of bishop Raffay was printed above the map's title.

The Latin text is placed in the upper right part, which also includes all the other textual data, under the title "Nomina" - names. The text contains historical facts about significant places of the diocese; it is written within the drawing of the folded piece of paper. The approximate, shortened content is:

Nomina - Names of old antique places, that had a diocese, abbey or praepositus in the area of these dioceses. BANOSHTOR or BONONIA (Bandštor)

- $\quad$ established for the czar Antonio Pio;

- the seat of the Dioceses of Syrmia and the crusade Order of Saint John of Jerusalem.

ERDÖD former TEUTOBURG (Erdut)

- a town which was latter named Erdut after the forests that surrounded it.

ESSEKINUS former MURSA (Osijek)

- established under Octavian or according to some under Hadrian;

- $\quad$ was christened by Saint Clement, the disciple of Saint Peter and is the seat of the diocese.

KAMENITZIUM former CUSUM (Kamenica)

- $\quad$ was named KÖE and KEU in the Middle Ages;

- was the seat of the Dioceses of Central Syrmia.

ILLOKINUM former UJLAK (Ilok)

- $\quad$ residence of the Bishop of Syrmia;

- where duke UGRIN established a Franciscan monastery in 1451 .

MITROVITZIUM former SYRMIUM (Mitrovica)

- the seat of the early Christian diocese and archdiocese;

- according to the tradition the founder bishops were the disciple of Saint Peter - Saint Epenetas and the disciple of Saint Paul - Saint Andronik;

- was demolished by the Avars in 580;

- under Justinian I its jurisdiction was moved to Justinianopol for the entire Downer Pannonia;

- in 1229 Kaloča's archbishop UGOLIN renewed the Diocese of Syrmiawith a seat in Čerević, then in 
Petrovaradin and finally in 1773 this diocese was conjoined with the Diocese of Đakovo.

NUSHTAR (Nuštar)

- praepositus (convent) of the Holy Ghost since 1225.

SLANKAMEN former RITTIUM

- Roman town.

SEMLINUM (Zemun)

- according to many historians its name was SINGIDUNUM;

- $\quad$ it was the seat of the early Christian diocese according to the tradition and was established by Saint Peter and his disciple Saint Clement;

- was destroyed by czar Justinian and reconstructed.
VINKOVCZE (Vinkovci) in the Roman Empire formerly known as CIBALIS

- $\quad$ there are still Roman remains in the town;

- their bishops were killed during the persecutions; bishop Euzebie and the founder of the lector school Saint Pollio, who died as a martyr during the reign of Diocletian in 1304.

\section{SEDES}

- the seat of the Diocese of Bosnia;

- Đakovo became the seat of the diocese after 1239 when Bosnian bishops moved from Bosnia to Slavonia.

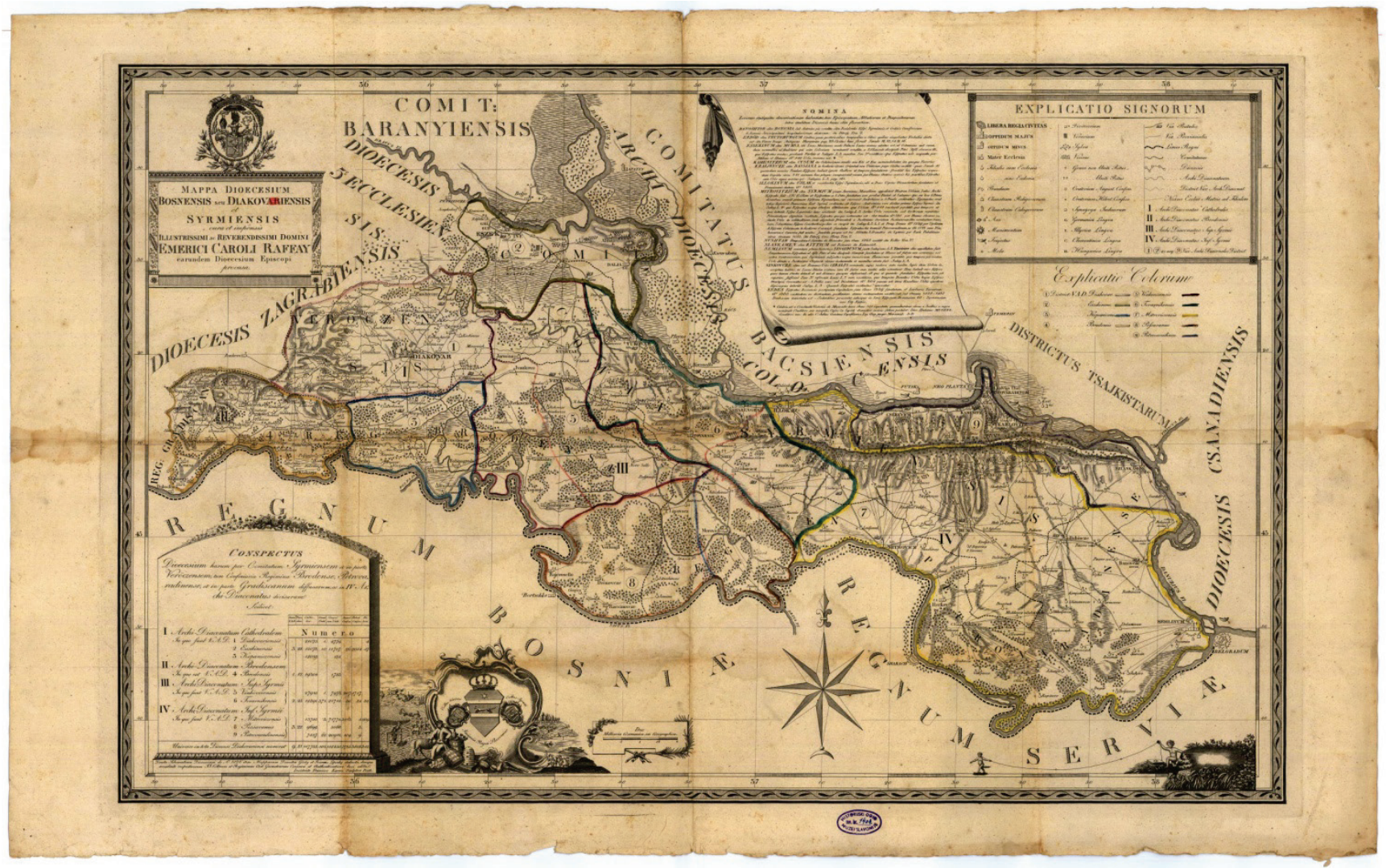

Figure 1 Scaled-down Map of the Bosnia or Đakovo and Syrmia Diocese [3]

The legend and the colour legend are placed in the upper right part of the map sheet. After printing the map was additionally coloured by hand in order of better noticing the existing deaneries (in Fig. 2 and Fig. 3, in Tab. 1 and Tab. 2). The applied symbols both for the ecclesial and the secular objects are replicative symbols [4].

The table with the archdeaconries, deaneries and parishes of the Diocese of Đakovo and Syrmia is placed in the bottom left corner of the map's sheet which also contains the statistical data about the number of members of the respective religions (Catholics, Greek Catholics, Orthodox, Lutherans, Calvinists and Jews) (in Tab. 3).

There is a short text above the table that reads:

"CONSPEKTUS" - overview of the dioceses divided into four archdeaconries and distributed in the Syrmia County, partly in the Virovitica County, in the area of Vojna Krajina - Brod, Petrovaradin and partly in Gradiška.

The panorama of Đakovo is placed in the space between the table and the imprinted coats of arms, however in its map there are no additional explanations. The bishop's court is placed in the centre of the panorama with a late Baroque cathedral built after the liberation from the Turks. There is a Franciscan monastery with a facade of the Franciscan church on the left from the court. On the far left side there is a canonical curiae. On the right side from the bishop's court there are canonical curies and the beginning of the town is drawn. In the background of the panorama there is a drawing that symbolizes the wealth of the diocese (fields of grain, vineyards, fishing ...). 


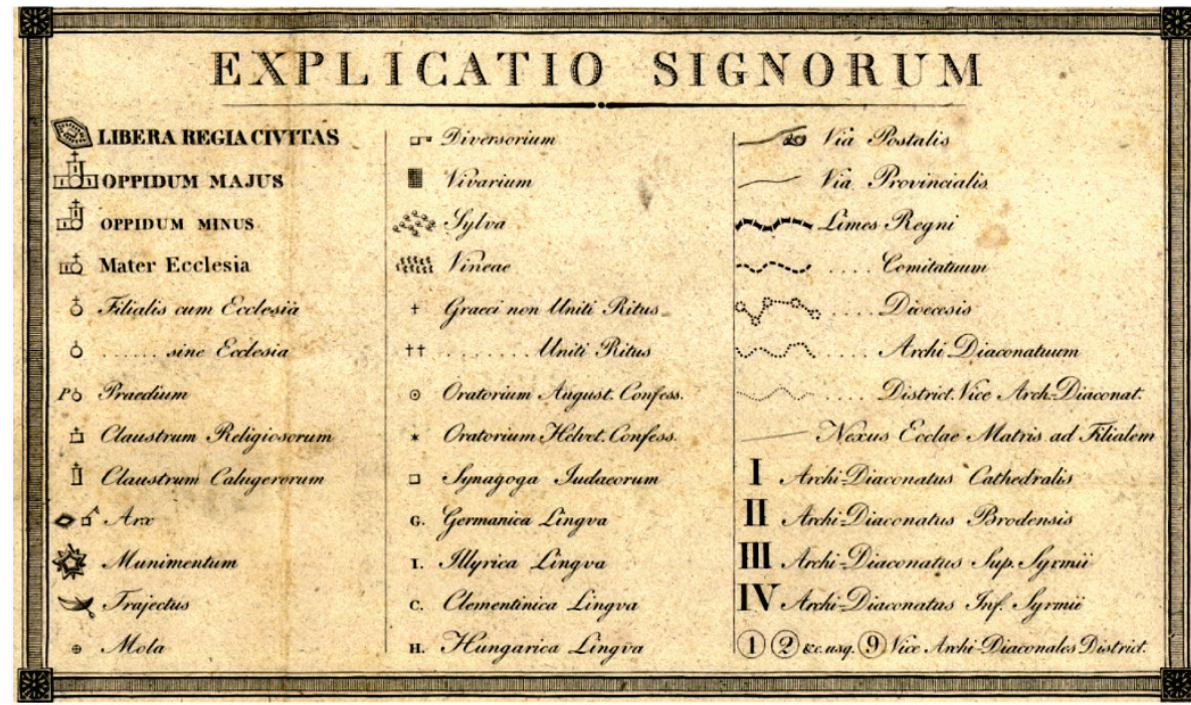

Figure 2 Legend on the Map of the Bosnia or Đakovo and Syrmia Diocese [3]

Table 1 Translation of the legend's content of the Map of the Bosnia or Đakovo and Syrmia Diocese [3]

\begin{tabular}{|c|c|c|c|c|c|}
\hline \multicolumn{6}{|c|}{ Legend } \\
\hline & Free royal city & 口" & Tavern & & Postal way \\
\hline ती & Bigger city & & Menagerie & & Regional way \\
\hline त्व & Smaller city & $e^{2^{2} z^{2}} z^{2}$ & Forest & 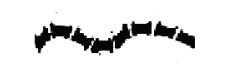 & Border of the kingdom \\
\hline III & Parish church & tetet & Vineyards & & County border \\
\hline$t$ & $\begin{array}{l}\text { Branch with a } \\
\text { church }\end{array}$ & + & Orthodox religion & & Border of the diocese \\
\hline & $\begin{array}{l}\text { Branch without a } \\
\text { church }\end{array}$ & $t+$ & Greek Catholic religion & 8 & Border of the archdeaconry \\
\hline$P o$ & Farmstead & 0 & Lutheran oratory & & Border of the deanery \\
\hline 直 & Cloister & 标 & Calvinistic oratory & & $\begin{array}{l}\text { Connection between the } \\
\text { parish church and the } \\
\text { branch church }\end{array}$ \\
\hline 1 & Monastery & $\square$ & Synagogue & I & Cathedral archdeaconry \\
\hline A & $\begin{array}{l}\text { Archeological site, } \\
\text { tower }\end{array}$ & G. & German language & II & Archdeaconry of Brod \\
\hline & Military fortress & I. & $\begin{array}{l}\text { Croatian } \\
\text { (Illyrian) language }\end{array}$ & & $\begin{array}{l}\text { Archdeaconry of Upper } \\
\text { Syrmia }\end{array}$ \\
\hline & Ferry & C. & $\begin{array}{l}\text { Albanian (Climentinian) } \\
\text { language }\end{array}$ & IV & $\begin{array}{l}\text { Archdeaconry of Lower } \\
\text { Syrmia }\end{array}$ \\
\hline$\phi$ & Quay & H. & Hungarian language & (1)(2)ecing. (9) & Deaneries \\
\hline
\end{tabular}

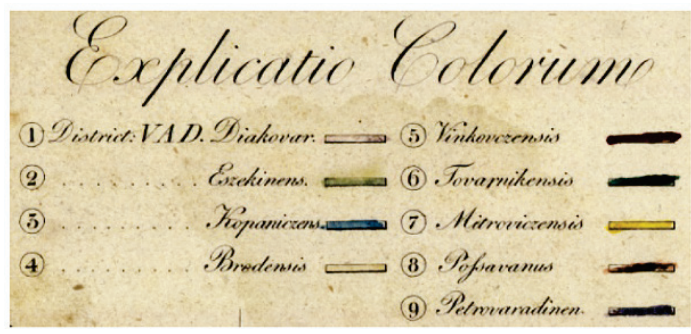

Figure 3 Colour legend on the Map of the Bosnia or Đakovo and Syrmia Diocese [3] 
Table 2 Translation of the colour legend's content of the Map of the Bosnia or Đakovo and Syrmia Diocese [3]

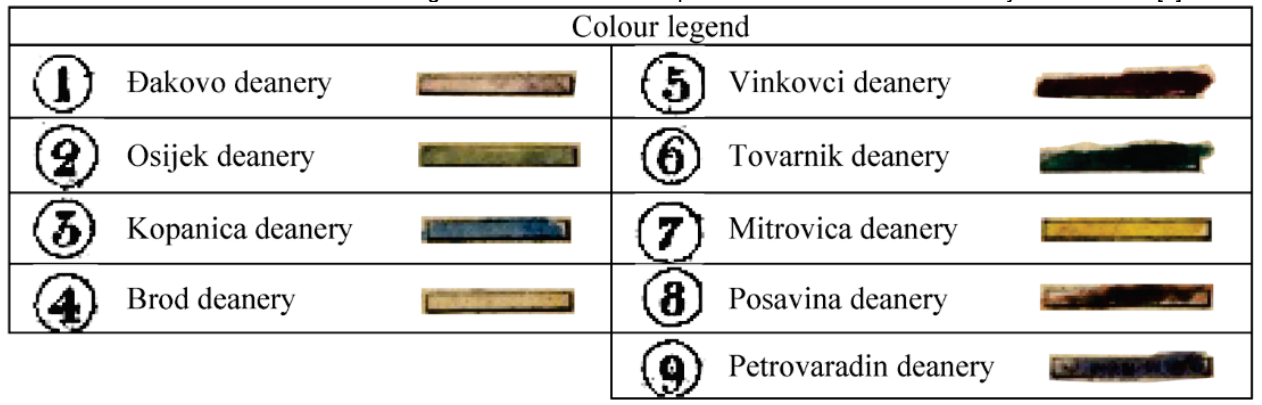

Table 3 The division of the Diocese of Đakovo and Syrmia on archdeaconries, deaneries and parishes that contains the statistical data about the number of members of

\begin{tabular}{|c|c|c|c|c|c|c|c|c|}
\hline & 己. & $\frac{\sqrt[n]{7}}{\sqrt{E}}$ & 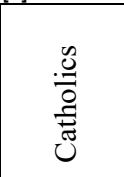 & 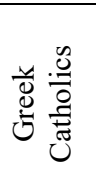 & 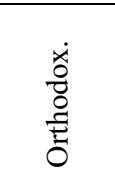 & 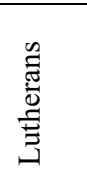 & $\frac{\sqrt[n]{n}}{\sqrt[n]{\Xi}}$ & $\stackrel{\infty}{2}$ \\
\hline & \multicolumn{8}{|c|}{ Number } \\
\hline \multirow{2}{*}{$\begin{array}{l}\text { I Archdeaconry cathedral } \\
\text { Deanery: } 1 \text { Đakovo } \\
2 \text { Osijek } \\
3 \text { Kopanica }\end{array}$} & & & & & & & & \\
\hline & 3 & 22 & $\begin{array}{l}21075 \\
12073 \\
18059\end{array}$ & $\begin{array}{r}1 \\
10\end{array}$ & $\begin{array}{r}4779 \\
11707 \\
138\end{array}$ & 26 & 2044 & $\begin{array}{r}4 \\
47\end{array}$ \\
\hline \multirow{2}{*}{$\begin{array}{l}\text { II Archdeaconry Brod } \\
\text { Deanery: } 4 \text { Brod }\end{array}$} & & & & & & & & \\
\hline & 1 & 12 & 19304 & & 1783 & & & \\
\hline \multirow{2}{*}{$\begin{array}{c}\text { III Archdeaconry Upper Syrmia } \\
\text { Deanery: } 5 \text { Vinkovci } \\
6 \text { Tovarnik } \\
\end{array}$} & & & & & & & & \\
\hline & 2 & 25 & $\begin{array}{l}27910 \\
18391 \\
\end{array}$ & $\begin{array}{r}1 \\
371 \\
\end{array}$ & $\begin{array}{r}7973 \\
21718 \\
\end{array}$ & $\begin{array}{r}207 \\
30 \\
\end{array}$ & $\begin{array}{r}1717 \\
31 \\
\end{array}$ & 32 \\
\hline \multirow{2}{*}{$\begin{array}{l}\text { IV Archdeaconry Lower Syrmia } \\
\text { Deanery: } 7 \text { Mitrovica } \\
8 \text { Posavina } \\
9 \text { Petrovaradin } \\
\end{array}$} & & & & & & & & \\
\hline & 3 & 22 & $\begin{array}{r}13740 \\
9699 \\
7487 \\
\end{array}$ & $\begin{array}{r}3 \\
22 \\
\end{array}$ & $\begin{array}{r}71774 \\
8066 \\
20912 \\
\end{array}$ & $\begin{array}{r}3413 \\
109 \\
\end{array}$ & $\begin{array}{l}4 \\
3 \\
9\end{array}$ & 259 \\
\hline Total & 9 & 81 & 1447738 & 408 & 148850 & 3785 & 3808 & 342 \\
\hline
\end{tabular}

In the central bottom part of the map there is a graphical scale in geographic or German miles that is framed with a rectangular vignette decorated with a drawing of leaves. The numerical scale is determined on the basis of the measures of the meridian arc lengths on the map [5], on the basis of graphical scale as well as on the basis of the relationship of the distances between the settlements on the map and the calculated distances from the known geodetic coordinates of churches in the villages (trigonometrical points). The rounded scale totals 1:250 000 (in Fig. 4).

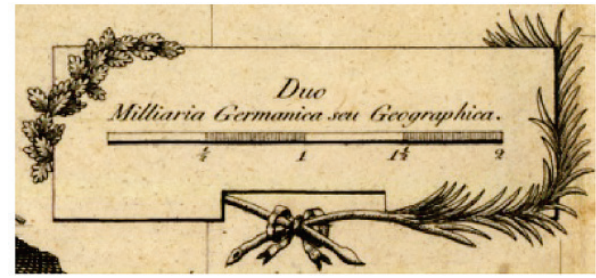

Figure 4 Graphical scale of the Map of the Bosnia or Đakovo and Syrmia Diocese [3]

Right from the graphical scale there is a beautifully drawn eight-pointed star which specifies the north direction.

In the bottom right corner there is a classicistic drawing of two land surveyors holding a stretched surveyor's chain.
In the beginning of the $19^{\text {th }}$ century, the Diocese of Đakovo and Syrmia bordered with the following counties and dioceses: on the north, along the river Drava it bordered with the Baranja County, on the northeast with the river Danube it bordered with the Bačka County i.e. the Archdiocese of Kaloča that is followed by the Diocese of Čanad. It bordered with the Kingdom of Bosnia along the river Sava on the south of the observed area, and it bordered with the Kingdom of Serbia from the mouth of the river Drina into the Sava to the mouth of the river Sava into the Danube. On the west from Valpovo on the Drava and to Dubočac on the Sava, it bordered with the Zagreb diocese and on the northwest with the Diocese of Pécs.

\section{ASSUMED SOURCE MAPS}

In the late 18th century, during the reign of czar Joseph II, the so called Josephinian topographical survey of the Croatian territories in the Austro-Hungarian Monarchy was conducted. In the period from 1764 to 1787 detailed topographic maps had been made in the scale 1:28 800 [6]. Certain authors had access to these maps and thus new topographic maps were created.

It is assumed that the Map of Hungary was the original map of the Map of the Bosnia or Đakovo and Syrmia Diocese, whose author was Joannis Lipszky, and its original title was "Mappa Generalis regni Hungariae". It was printed in Pécs in 1806 and it consisted of 12 sheets in 
scale 1:500 000 with the total dimensions $210 \times 161 \mathrm{~cm}$. The map was engraved by G. Prixner and F. Karaca. A possible original map might also be the first map of Hungary by Ignaz Müller "Mappa Geographica novissima Regni Hungariae", Vienna 1769, on 16 sheets, dimensions $248 \times 204 \mathrm{~cm}$, scale 1:375 000, engraved by I. C. Winkler $[7,1,2,8]$.

Lipszky's Map of Hungary was made in a normal conical projection with the central meridian $38^{\circ}$ from Ferro. The same cartographic grid was applied to the Map of the Bosnia or Đakovo and Syrmia Diocese.

\section{ECCLESIASTICAL CONTENT}

In the text that is printed on the map with the title "Nomina" (Names) there is numerous data about the foundation of the respective convents, about the repositioning of the seats of the dioceses over time and about the foundation of the respective dioceses. It is visible that the Diocese of Syrmia was renewed during the $13^{\text {th }}$ century under the Kaloča's archbishop Ugolin and in the late $18^{\text {th }}$ century the Diocese of Đakovo and the Diocese of Syrmia were unified. After the Bosnian bishops moved to Slavonia in 1239, Đakovo became the seat of the diocese $[9,10,11]$.

The borders of the Diocese of Đakovo toward the Diocese of Zagreb were established in the middle of the $19^{\text {th }}$ century when the area surrounding Požega and the area surrounding Našice were annexed to the Diocese of Zagreb and the Diocese of Pécs was limited on the areas north of the river Drava.

When in 1826, the Map of the Bosnia or Đakovo and Syrmia Diocese appeared, the dioceses were divided into 4 archdeaconries and 9 deaneries and the 81 parishes are mentioned in table 3 . The borders between the dioceses, archdeaconries and deaneries are shown with linear cartographic symbols and in order to enhance the visibility of the deaneries they were later highlighted by handcoloured additional lines along the linear graphic symbols.

The cartographic symbols for bigger and smaller cities are presented by clear drawings of church facades and on the map some other objects can also be seen: parish church, a branch with a church and without a church, monastery and convent, Orthodox, Greek Catholic, Lutheran, Calvin and Jewish religion (in Tab. 4).

\section{SECULAR CONTENT}

The secular content on the Map of the Bosnia or Đakovo and Syrmia Diocese is various. On the map Osijek, Petrovaradin and Zemun are shown as free royal towns and 7 settlements are included into bigger towns (Đakovo, Vinkovci, Vukovar, Ilok, Mitrovica, Ruma, Karlovci) and there are 12 smaller towns (Dalj, Brod, Nuštar, Sotin, Šid, Šarengrad, Kukojevci, Erdevik, Irig, Čerević, Kamenica, Slankamen). Villages are shown with cartographic symbols for parish churches and branches with or without churches.

The following farmsteads are shown:

Đakovo deanery - Ovile Dominale;

Osijek deanery - Derzanicza, Klissa;

Tovarnik deanery - Grabovo, Laze, Đeletovci, Ivanci;
Mitrovica deanery - Prailovo, Begovina, Xirovacz, Jelencze, Meges, Selevrencze, Dobrodol, Bankovcze, Lukovo, Vojkovcze.

Military fortresses are presented in the area of the towns Osijek, Šabac, Zemun, Beograd and Petrovaradin.

There were archeological sites in the area of Ilok, Bač and Morović and a tower in the area of SlobodnaVlast, Erdut, Kolođvar and Šarengrad.

The symbol for a menagerie can only be found in the area of Đakovo and Tenja.

The postal stations are presented with a post horn along the postal ways (Osijek-Đakovo-Vrpolje, Brod-VrpoljeVinkovci-Tovarnik-Šid-Kukojevci-Čalma, Osijek-VeraVukovar-Ilok-Čerević-Kamenica-Petrovaradin-KarlovciBanovci-Zemun,

Čalma-Mitrovica-Ruma-Gubinci-Banovci-Zemun).

The cartographic symbols for taverns can be found along these important traffic routes. Thus, there are 4 taverns on the route Osijek-Čepin, there are also 4 taverns on the route Osijek-Klisa, one tavern between Pačetin and Nuštar, and Gibarac and Erdevik, 2 taverns between Trpinja and Vukovar, one tavern in the area of Maradik and 4 taverns between Čerević and Kamenica.

The bridges on the map are shown in the area of Osijek on the river Drava, in the area of Petrovaradin on the Danube and two bridges in the area of Ašanj across the trench Jarčina.

Ferries can mostly be found on the Danube in the area of Dalj, Opatovac, Ilok, Neštin, Slankamen, Surduk, Karlovci and Čerević and on the Sava in the area of Belgrade.

There are many quays on the Drava in the area of Osijek, on the Danube in the area of Sarvaš, Aljmaš and Dalj, Vukovar, Opatovac and Šarengrad, Banovci and Neštin and in the area of Čerević. On smaller unnamed river courses and streams, quays are presented in the area of Đakovo and Vučevci, in the area of Bogdanovci, Tompojevci, Novaki, Privina Glava and Erdevik and in the area of Bešenovo.

There are letter signs in the legend which present the languages which were spoken in the respective places within the deanery. Thus, the Croatian language marked with the letter I. (Illyrian language) was spoken in all 9 deaneries, and the German language as official language marked with the letter $\mathrm{G}$. was added to the cartographic symbols for bigger towns eg. Osijek, Đakovo, Brod, Vinkovci, Vukovar and Ilok. The period in which the map was published coincides with the Hungarian tendencies so that Hungarian language marked with the letter $\mathrm{H}$. can be found near the following places: Osijek, Sotin and Kukojevci. The Albanian language marked with the letter C. (Climentinian language) can be seen in the area of the villages Herkovci and Nikinci near Mitrovica.

\section{NATURAL CONTENT}

The cartographic representation of the Earth's relief, waters and vegetation is considered to be natural content.

The relief is shown as a stretch of hills without marked altitude or relative heights because there were almost no original maps at that time. Hills are shown with slopes, the so called hachure, by means of which it is possible to develop space sense. There are no oronyms on this map. 
The waters on the map are shown with river courses and streams, channels and swamps. Swamps are represented by horizontal dashed lines and they can be seen in the areas along the Danube, the Sava, in the area of Baranja, and by some forests (eg. Spačva).

Thus near Brod there is a swamp Mersonja and south from Osijek Kologyvar and Palacza. Channels are shown in the area of Sarvaš and in the area of BabinaGreda.

Rivers with a wider course (the Danube, the Drava, the Sava and other rivers closer to the river mouth) are shown as two lines, and the space in between is filled with a row of thin lines that follow the river course. Hydronyms which are exclusively in Latin stand for the following rivers: the Sava (Savus Fl.), the Drava (Dravus Fl.), the Danube (Danubius Fl.), and only the mouths of the Bosna and the Drina into the Sava, the Danube tributaries, the Vuka and the Tisa (Tibiscus Fl.), the Sava tributaries, the Bosut and the Berava and the Bosut tributaries the rivers Bid (Bigi Fl.) and Spačva (Spacsva Fl.).

The vegetation is shown with illustrations of forests and vineyards. Forests can be seen almost on the whole map. Vineyards, categorized by deaneries, are shown in the following locations:

Đakovo deanery - Pridvorje, Varoš, Trnava;

Osijek deanery - Aljmaš, Erdut, BijeloBrdo;

Tovarnik deanery - Bogdanovci, Vukovar, Šarengrad, Babska, Erdevik;

Petrovaradin deanery - Čerević, Beočin, Kamenica, Karlovci;

Mitrovica deanery - Ilok, Šišatovac, Grgurevci, Opovo.

\section{CONCLUSION}

The Map of the Bosnia or Đakovo and Syrmia Diocese from 1826 is a valuable historical document which deals with ecclesiastical, secular and natural content of this area.

All natural and social sciences dealing with space use maps for acquiring knowledge of the interdependencies of various space objects, in order to detect, investigate and locate different thematic data, as well as to present specific intentions.

The Map of the Bosnia or Đakovo and Syrmia Diocese from 1826 is an example of the map that can be used for spatial analysis and researches, hypotheses proving and gaining new knowledge.

Since this paper involves translations of the Latin texts and statistical data presented inside and outside the map, it opens up new possibilities for further researches of past phenomena and conditions in the area, a historical overview of the diocese creation and similar.

Research work on any map, and also on this one, will continue as long as maps are needed and useful. By looking into the past, we can draw conclusions about changes that happened in the meantime and when is the right time to make a new version of a map.

\section{Acknowledgements}

We thank most sincerely the Museum of Slavonia in Osijek, which gave us permission to publish the scaled down maps in our article.

\section{REFERENCES}

[1] Lovrić, P. (1990). Prilog poznavanju Szemanove karte Zagrebačke biskupije 1:150000. Geodetski list, 10-12, 301314.

[2] Marković, M. (1993). Descriptio Croatiae. Zagreb, HR: Naprijed.

[3] Görög, D. \& Lipszky, J. (1826). Mappa Dioecesium Bosnensis seu Diakovariensis et Syrmiensis, Pešta. In Museum of Slavonia in Osijek (accession number P-1404).

[4] Lovrić, P. (1988). Opća kartografija. Zagreb, SN Liber.

[5] Peterca, M., Milisavljević, S., Radošević, N., \& Racetin, F. (1974). Kartografija. Belgrade, Izdanje Vojnogeografskog instituta.

[6] Senđerđi, J. (1958). Prvi zemaljski-jozefinski premjer. Geodetski list, 64-73, 382-396, 482-505.

[7] Pandžić, A. (1988). Pet stoljeća zemljopisnih karata Hrvatske. Izložba Povijesnog muzeja Hrvatske, Muzej za umjetnost i obrt, Zagreb, 112-123.

[8] Lapaine, M. \& Kljajić, I. (2009). Hrvatski kartografi. Biografski leksikon. Zagreb, Golden marketing-Tehnička knjiga.

[9] Povijest Đakovačko-osječke nadbiskupije. (2016, November 17). Retrieved from http://www.djos.hr/ index.php/sredisnje-ustanove/nadbiskupija

[10] Majdandžić-Gladić, S. (2016, November 17). Povijesni orisi Đakovačko-osječke nadbiskupije i Srijemske biskupije. Retrieved from http://bibijanamajglad.blogspot.hr/2009/03/povijesni-orisi-akovackoosjecke 25.html

[11] Hrvatska enciklopedija - Đakovačko-osječka nadbiskupija. (2016, November 17). Retrieved from http://www.enciklopedija.hr/natuknica.aspx?ID=16890

\section{Contact information}

Brankica MALIĆ, PhD/Geodesy, Associate Professor (Corresponding author)

University Josip Juraj Strossmayer of Osijek,

Faculty of Civil Engineering and Architecture in Osijek

Vladimira Preloga 3, 31000 Osijek, Croatia

E-mail: bmalic@gfos.hr

Stanislav FRANGEŠ, PhD/Geodesy, Full Professor

University of Zagreb, Faculty of Geodesy,

Andrije Kačića Miošića 26,10000 Zagreb, Croatia

E-mail: stanislav.franges@geof.hr 